\title{
The Impacts of Smartphones on Early Childhood Language Development
}

\author{
Nurmalina 1 , Deddy Gusman* 2 \\ DOI : $10.35445 /$ alishlah.v13i3.765
}

\begin{tabular}{ll}
\hline Article Info & Abstract \\
\hline $\begin{array}{l}\text { Keywords: } \\
\text { Gadget; }\end{array}$ & $\begin{array}{l}\text { This study aims at determining the impact of using smartphones on aspects of } \\
\text { early childhood language development. This analytical descriptive study was } \\
\text { Language Development } \\
\text { conducted among early childhood children. Documentation was the technique } \\
\text { for collecting the data whereas analysing the data was the library research } \\
\text { method. Allowing children to use smartphones which are still at an early age } \\
\text { with adequate time control, does not interfere with their language development. } \\
\text { Children with these criteria can still develop normally. However, the undesirable } \\
\text { effects of using smartphones outweigh the constructive effects. In conclusion, } \\
\text { early childhood is already familiar with smartphones and is strongly dependent } \\
\text { on them in their activities. With a high quantity of time, children's language } \\
\text { development is notoptimal and tends to behampered. }\end{array}$
\end{tabular}

\begin{abstract}
Abstrak
Penelitian ini bertujuan untuk mengetahui dampak penggunaan gawai terhadap aspek perkembangan bahasa anak usia dini. Penelitian deskriptif analitik ini dilakukan di kalangan anak-anak usia dini. Teknik pengumpulan data dalam penelitian ini adalah dokumentasi. Teknik analisis data yang digunakan dalam penelitian ini adalah metode penelitian kepustakaan (library research). Pemberian gawai pada anak yang masih usia dini dengan pengontrolan waktu yang tidak berlebihan tidak mengganggu perkembangan bahasa anak mereka. Anak-anak pada kriteria ini masih bisa berkembang dengan normalnya. Namun, efek negatif dari penggunaan gawai lebih banyak dari pada efek positifnya. Kesimpulan dari penelitian ini adalah anak-anak usia dini sudah mengenal dan termasuk pada kategori ketergantungan terhadap gadget dalam beraktivitas. Dengan kuantitas waktu yang tinggi, maka perkembangan bahasa anak tidak maksimal dan terhambat.
\end{abstract}

Kata kunci:

Gadget;

Anak UsiaDini;

Perkembangan

Bahasa

\footnotetext{
${ }^{1}$ Un iv ersitas Pahlawan Tuanku Tambusai, Riau, Indonesia Em ail: nurmalina18des@gmail.com

2 Universitas Pahlawan Tuanku Tambusai, Riau, Indonesia

Em ail: deddyg@gmail.com*
} 


\section{INTRODUCTION}

The gadget is one of the technological advances used equally at all ages, including children under five years (Kementerian Komunikasi dan Informatika Republik Indonesia, 2015). There is a rapid increase in motor development, speech-language, and freedom of socialization (Rumini dan Sundari, 2004). Excessive use of devices at this age can interfere with the development process (Sigman, 2011). When a child is addicted to a device, the child does not care about the environment.

Internal and external factors affect the process of child development. Children are tiny humans who have potential that still needs to be developed (Nurmalina, 2016). Providing smartphones for children is one of the external socio-economic factors and parenting. The results of research conducted by Fajariyah show that the intensity of the use of smartphones has a significant impact on the development of socialization of independence, language, fine and gross movements. This is evidenced by the incomplete developmental tasks at each stage of the children's age. The higher the intensity of the use of the device, the more excellent the opportunity for children to experience possible developmental deviations (Fajariy ah et al., 2018).

Smartphones directly affect the language and social development of children. If children communicate directly with their environment, both aspects of development can be better. On the other hand, children who are used to smartphones are not. Smartphones can distinguish the dimensions of an object and affect the children's mindset (A, 2017). The use of smartphones certainly affects the language development of children. Developing a child's language is the child's ability to respond to sounds, obey commands, and speak politely. Language develops very quickly and becomes the basis for further development in toddlers' lives ( Salnita, Atmazaki, 2019). The device screen always displays an image of the same size, the size of which must be different in natural conditions so that it interferes with little one's fine motor skills. Early childhood is people aged o-8 years experience rapid physical and mental growth (Yunita, 2020). Static activity while operating a gadget can interfere with the overall developmental aspect of the children's movement. It is easier to establish social relationships without making someone directly socialize, namely only by using tools such as social media.

The smartphone is one of the products of this technology that has changed human communication behaviour by penetrating space and time. People who are thousands of kilometres away can communicate with each other while looking at each other and only by using gadget media. A gadget is a small electronic device that has a special function, such as a smartphone. Technology is essentially created to make human life easier and more comfortable (Junierissa, 2018). There are various forms of devices (Efendi, 2014) which states that computers or laptops, tablet PCs, and mobile phones or smartphones are smartphones. In Indonesia, such devices are called smartphones (Widiawati, L., Sugiman, H., 2014) which states that smartphones are sophisticated items developed by various applications that can offer various news media, social networks, hobbies and even entertainment. Another opinion (Jati dan Herawati, 2014) is that the gadget is a medium used as a means of modern communication and facilitates human communication activities.

Many children are familiar with devices such as computers or laptops, tablet PCs, and mobile phones or smartphones. Device-based applications such as game applications, from adventure games to colouring applications, learning to read and write letters, have attracted early childhood interest in smartphones. Based on the description above, the problems to be studied in this study can generally be explained by the following formula; How does the use of smartphones affect aspects of early childhood development?"

The use of smartphones that are not balanced in monitoring can hurt their use. The effect on humans is very influential from a health point of view to a social point of view-no exception for early childhood. According to the National Association For The Education Young Children 
(NAEYC), early childhood is children aged o-8 years. This period is a process of development and growth in various aspects of human life.

Early childhood is a crucial period in studying human life in terms of brain development, intelligence, personality, memory, and other aspects of development. Growth and development today can be disrupted in the future (Bredekamp, S. Rosegrant, 1992). It is essential to understand the principles of child development to get a general idea of a child's behaviour at a particular stage. Development is related to improving the structure of body functions, including the ability to move as a whole, gross movement, speech and language, as well as social and independence (Soetjingsih \& Ranuh, 2013).

Aspects of children's development according to (Syaodih, 2004), namely: (1) motor development, (2) thinking/cognitive development, (3) language development, (4) social development, and (5) emotional development. (Aswin Hadis, 2003), many impressions are broad enough to get things done, including physical, perceptual, linguistic, and social-emotional. (Catron, Carol E. \& Allen, 1999) explained six aspects of early childhood development, namely personal awareness, emotional health, social, communication, cognition, and motor skills. In this study, the developmental aspects discussed are physical, cognitive, language, and socio-emotional.

\section{METHOD}

This research method was a literature study consisting of data obtained from the library in encyclopedias, essays, dissertations, books, journals, documents, dictionaries, and journals (Khatibah, 2013). The literature study method in this research is to choose a topic, look for information on the topic in relevant journals, and compile a report. This research data comes from the literature in relevant journals/research, namely the last ten years with variables that match the research title. The documents are used as data collection techniques, namely looking for data about variables in journals/research.

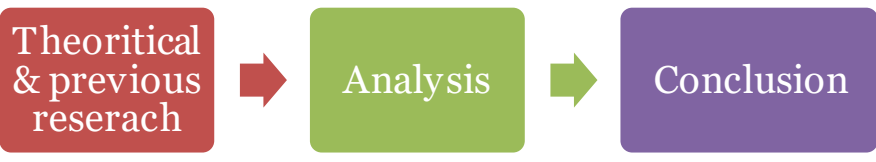

Figure 1. Research Design

\section{FINDINGS AND DISCUSSION}

In Fajariyah's research, most children with a high level of device use (75\%) questioned their developmental outcomes. Excessive use of tools can cause various developmental disorders, including speech disorders, emotional disorders, and cognitive disorders. As a result, this study found that the intensity of device use significantly affects the development of social-self-reliance, speech and language, movement fluency, and finally, overall movement. This is evidenced by the unfinished developmental tasks at each stage of a child's development (Fajariyah et al., 2018). Research findings (Nurmasari, 2016) also show a correlation between the severity of gadget use and delays in the development of speech and language aspects in toddlers. The direct impact of this developmental delay is that children rarely interact with the environment. Children prefer to sit and lie down to play with smartphones. It will directly interfere with the development of the child's overall mobility. In addition, it is more worrying to happen when the child starts to practice walking.

Gemi and Nyimas (2018) research results describe the relationship between the duration of gadget use and preschoolers' language development at PAUD Al Ilhamiyah Cakung, East Jakarta. 
From this study, it was concluded that most language developments were expected. A 2003 study at the Child Development Clinic of Banda Jakarta Hospital (Wenty, 2011) of about 60 children showed that some parents had language problems with their children. Of the 60 cases, only a small proportion occurred under the age of 1 year. Failure in relationships and communication between the ages of 0-3 is not seen as a permanent deficit but is considered a condition that is still very changing and developing. The research (Fajariyah, 2018) shows that 66 children participated in the study. Children with low gadget intensity showed appropriate developmental test results, while high gadget use intensity showed dubious test results. With moderate strength and positive direction (correlation coefficient $=0.521$ ), there is a relationship between the intensity of gadget use and the development of children aged 24-60 months ( $p=0.000)$.

Yulsyo (2013) research confirms that some games can be a great way to help children learn and encourage them to read for children who cannot read well. Many games can help children learn by reading, which is more fun because they are decorated with colourful characters and exciting music. In addition, while playing, children also need to read every command given through game characters and game descriptions. Therefore, children can learn to read by playing indirectly. Furthermore, Yulsyo's research explained that smartphones:

a. Interfere with Receptive Language Development

Receptive language is also known as passive language, the development of children's ability to hear in the receptive language in early childhood, for example listening to fairy tales and songs. This ability can respond to direct learning where the child can answer the questions asked. The child is able to react when communicating with others; for example, the child can respond when he is conversing with people in his environment. In fact, with gadgets, children are only interested in features that make them not interested in interacting with their environment.

b. Interfere with Expressive Language Development

Receptive language is the ability to express. In early childhood, this ability is expected to express and express various needs, desires and feelings verbally. Able to encourage children when speaking clearly and firmly so that they can be understood. Encourage articulation in language. They were helping children understand when interacting with their social and environmental environment.

c. With smartphones, children cannot speak Indonesian well.

d. Prevents recognizing mother tongue in childhood (B1).

e. Children are unable to communicate non-verbally

This is because smartphones allow children to spend time with smartphones to limit facial expressions and expressions of wants and needs through spoken and non-verbal language.

f. Smartphones reduce children's desire not to use eye contact when interacting.

Widhianawati's research suggests that if children are given toys in the form of smartphones at this time, it will affect the language acquisition process that is not by their level of development. This can happen because of a one-way interaction because children are addicted to smartphones. However, language is an essential part of life. The language of one individual with another individual will be connected to each other through the language process (Jafri, Yendrizal., 2020).

Using smartphones also impacts children's speech delays because smartphones inhibit direct communication with the surrounding environment (Yulsyofriend et al., 2019). According to Ferliana, children and smartphones are the game's most important rules (Sulton, 2013). One of the negative impacts of using smartphones is that it inhibits language skills (children who are accustomed to using smartphones will tend to be silent, often imitate the language they hear, close themselves off and are reluctant to communicate with friends or their environment) 
Technology affects children because technological devices are the most effective learning media. The presence of walking pictures, sound effects, or the appearance of songs makes learning media very popular with children through technology. Moreover, technological advances can also help children's creativity if the user is balanced with their interaction with their environment. They were making minors too free. The use of very advanced technology such as smartphones can change children's behaviour, so that the role of parents becomes crucial (Efendi, 2014).

Research by (Trinika, 2015) showed that smartphones affect the psychological development of children. This result is by the quadratic test, where the value obtained is 0.005 . Because the p-value <0.05, it can be concluded that the use of smartphones affects the psychological development of children. In Wulansari's research, the results of this study are that smartphones can affect brain development in childhood. Smartphones are also harmful radiation that can affect a children's brain and nerves. The effects of using smartphones on children's development are both positive and negative.

Other research on smartphones also concludes that their smartphones are used only as a means of entertainment. Used smartphones cannot be used as learning media. Second, children's study time is not well organized. This is indicated by the lack of children's learning programs at home. Third, smartphones hurt children if they do not manage their study time well, in addition to poor parental control over children, village government policies regarding time limits for using smartphones-absence, unhelpful environment, and so on.

\section{Parental Assistance in Early Childhood in the Use of Digital Technology}

Parental assistance in early childhood is essential. It is necessary to reduce the negative effect on its use. When parents play with smartphones, parental supervision and attention are lacking because parents do not minimize the impact of smartphones on children's development and growth. The negative and positive effects of smartphones in shaping children's character can be seen in their children through education, teaching, and communication (Sinta, Muhamad Ali, 2018). In the era of the information technology revolution, it has led to the spread of communication technology. It can influence the formation of new societies (Webster, 2006). The role of parents is vital in forming a new society. In the digital era, parents must be careful and play an active role in the growth and development of children without relying on smartphones (Alia, Tesa, 2018). The children's habits understand that life should be more accessible. In the end, the child will choose to ease the difficulty and avoid the difficulty. As a result, children become weaker in patience and concentration and are quick to demand that people give them whatever they want (Anggrahini, 2013).

\section{Determination of Gadget Usage Time Limit}

The children can not be separated with smartphones. The role of a parent is important in this situation. They need to control children in playing smartphones. According to Romo, playing with smartphones for a long time and continuously every day can ensure that children develop into antisocial personalities. Children now spend more time playing with smartphones than playing with their peers, leading to individualistic and selfish nature and a lack of sensitivity to the environment (Jonathan, 2013). Parents need to set aside time to play musical instruments in early childhood because: previously, these smartphones were only used as entertainment media. Smartphones could not be used as learning media. Second, children's study time is not well organized. This is indicated by the lack of learning programs for children at home. Third, smartphones hurt children who have smartphones when their study time is not managed properly. Besides, those children have difficulty throwing away smartphones, weak parental control. Lack of village government policies is regarding time limits for using smartphones, unsupportive environment etc. (Sandrawita, 2019). 
If the duration of playing smartphones for early childhood is excessive, it will affect the activeness of children's activities. (Al-Ayouby, 2017) in his article wrote about the high intensity and duration of gadget use that is open to most sports, so that young children are limited in using smartphones because they are not suitable or suitable for use at their age. They play a lot of games without interacting with other people or coworkers.

Educational games combine the principles of play that benefit from creating educational materials with technology that integrates entertainment into learning (Zemliansky, P., Wilcox, 2010). The development of the times also encourages the creation of applications that can support children in wanting to learn in a more fun way. Smartphones have the potential to satisfy children with the knowledge they have acquired quickly, so they think that what they get through the internet or other technology is the most complete and up-to-date knowledge.

\section{Diversion}

Smartphones are inseparable from life in today's digital era. The active participation of children in the digital era is a social phenomenon that needs to be studied (Corsaro, 2005). Because children depend on smartphones, they think smartphones are everything to them. If they leave the gadget, they will be angry and nervous. Most of their time is spent playing smartphones. As a result, apart from the lack of closeness between parent and child, they remain closed (Hastuti, 2012). Using smartphones at home makes it more challenging to communicate with children. They are ignored when parents ask them to do so and respond less. (Tan Paulus, 2016) in a study entitled "The Effect of Smartphones on the Development of Early Childhood Social Interaction". The results show that smartphones hurt the development of children's social interactions, one of which is that children become more inactive and slow to do activities that cause symptoms of obesity.

Another thing that parents can do to reduce their children's dependence on using smartphones is to increase their choice of activities outside the home. (Novitasari, 2016) explained in his research that children prefer to sit quietly in front of the gadget and enjoy the world on the gadget. (Mark Blades, 2013) explains that games encourage children to learn new concepts in a fun and entertaining context (Al., 2015). The study also found that sport can encourage more activity and encourage children to enjoy activities and adapt to children's learning through play. This study indicates that smartphones affect the social interaction of children aged 5-6 years. This is evidenced by the statistical value of $0.000<0.05,6$ (Novitasari, 2016).

\section{CONCLUSION}

From the results of analytical descriptive research in the form of the effect of smartphones on early childhood development, it can be concluded that parents who control their children at the right time will not interfere with their child's language development. Children with these criteria can still develop normally. The games they play on their smartphones still benefit early childhood reading skills because some of the game content requires them to recognize commands in the form of reading. However, the effects of using smartphones in early childhood, especially those that are not controlled by their parents, have more negative effects on the language development of early childhood. If it is too excessive, smartphones affect the ability to interact with the child's social environment. This, of course, will lead to poor communication problems in early childhood. This is mainly because children rarely interact with their environment. Even more frightening, children are no longer interested in social interaction. Even lazy to make eye contact with their interlocutor . 


\section{REFERENCES}

A, S. (2017). Smartphones make smart children? an evidence. Dalam: The impact of lifestyle modernization in child healthservice. Ikatan Dokter Anak Indonesia.

Al-Ayouby, M. F. (2017). Dampak Penggunaan Gadget Pada Anak Usia Dini Studi di PAUD dan TK. Handayani Bandar Lampung. https://onesearch.id/Record/IOS4198.27131\#holdings

Al., M. et. (15 C.E.). Catherine Monk, Claudia Lugo-Candelas, Caroline Trumpff Prenatal developmental origins of future psychopathology: mechanisms and pathways Annu. Rev. Clin. Psychol, 1, 317-344.

Alia, Tesa, \& I. (2018). Pendampingan Orang Tua pada Anak Usia Dini dalam Penggunaan Teknologi Digital [Parent Mentoring of Young Children in the Use of Digital Technology]. Polyglot: Jurnal Ilmiah, 14(1). https://doi.org/http://dx.doi.org/10.19166/pji.v14i1.639

Anggrahini. (2013). Dinamika komunikasi keluarga penggna gadget. Universitas Ilsma Negeri Sunan Kalijaga, Fakultas Ilmu Sosial dan Humaniora.

Anggraini. (2018). Perbedaan Tingkat Pengetahuan Tentang Diabetes Mellitus (Dm) Tipe Ii Sebelum Dan Sesudah Diberikan Edukasi Dengan Media Audio Visual Pada Penderita Diabetes Mellitus Tipe Ii Di Dusun Sentong Desa Karangduren Kecamatan Pakisaji Kabupaten Malang. Nursing News, https://doi.org/https://doi.org/10.33366/nn.v3i1.822

Aswin Hadis, F. (2003). Perkembangan Anak dalam Perspektif Pendidikan Anak Usia Dini. Buletin $P A D U, 2(1)$.

Bredekamp, S. Rosegrant, T. (1992). Reaching Potentials: Appropriate Curriculum and Assessment for Your Children. Washington, $D C, 1$.

Catron, Carol E. \& Allen, J. (1999). Early Childhood Curriculum A Creative-Play Modell. Merill, Prentice-Hall.

Corsaro, W. . (2005). The Sociology of Childhood (2ndedition), Thousand Oaks. Pine Forge Press.

Efendi, M. F. (2014). Pengaruh Gadget terhadap Anak Usia Dini. http://fuadefendi.blogspot.in/2014/01/pengaruh-gadget-terhadapperkembangan.html.

Fajariyah. (n.d.). Pendidikan Bidan Fakultas Kedokteran Universitas Airlangga. Departemen Ilmu Kesehatan Anak Fakultas Kedokteran Universitas.

Fajariyah, S. N., Suryawan, A., \& Atika, A. (2018). Dampak Penggunaan Gadget Terhadap Perkembangan Anak. Sari Pediatri, 2O(2), 101. https://doi.org/10.14238/sp20.2.2018.101-5

Gemi, R.S \&Nyimas, H. . (2018). Hubungan Durasi Penggunaan Gadget Dengan Perkembangan Bahasa Pada Anak Usia Prasekolah Di Paud Al Ilhamiyah Cakung Jakarta Timur Tahun 2018.

Hastuti. (2012). Psikolog PerkembanganAnak. Tugu Publisher.

Jafri, Yendrizal., L. D. (2020). Gadget Dengan Perkembangan Sosial Dan Bahasa Anak Usia $3-6$ Tahun. Prosiding Seminar Kesehatan Perintis, 3(1), 76-83.

Jati dan Herawati. (2014). Segmentasi Mahasiswa Program Studi Ilmu Komunikasi UAJY dalam Menggunakan Gadget. Journal Uajy.

Jonathan. (n.d.). Perancangan Board Game Mengenai Bahaya Radiasi Gadget Terhadap Anak. Universitas Kristen Pertra Surabaya.

Junierissa, M. (2018). Pengaruh Penggunaan Gadget Dalam Kehidupan. Jurnal KOPASTA, 5(2), 55-64.https://doi.org/https://doi.org/10.33373/kop.v5i2.1521

Kementerian Komunikasi dan Informatika Republik Indonesia. (2015). Indonesia raksasa teknologidigital Asia. url:Https://www.kominfo.go.id.

Khatibah. (2013). Pengembangan Perpustakaan sebagai Pusat Sumber Belajar dalam Kegiatan Instruksional pada IAIN-SU Medan. Jurnal Perpustakaan Dan Informasi, 7(2), 36-39. http://103.28.220.26/index.php?ref=browse\&mod=viewarticle\&article=298763

Mark Blades, F. C. B. dan C. O. (2013). Young children's ability to recognize advertisements in web 
page designs. British journal of Develpment Pschology. British Journal of Develpment Pschology, 27(1). https://doi.org/https://doi.org/10.1348/026151008X388378

Novitasari, W. dan N. K. (2016). Dampak Penggunaan Gadget Terhadap Interksi Sosial Anak Usia 5-6 Tahun. PAUDTeratai 5, 5(3).

Nurmalina. (2016). Hubungan Penerapan Bahasa Indonesia dengan Pengembangan Kepribadian Peserta Didik PAUD Kualu Ceria. https://doi.org/https://doi.org/10.31004/obsesi.v2i1.61

Nurmasari, A. (2016). Hubungan intensitas penggunaan gadget dengan keterlambatan perkembangan pada aspek bicara dan bahasa pada balita di kelurahan tambakrejo surabaya.

Rumini dan Sundari. (2004). Perkembangananakdan remaja. Rineka Cipta.

Sandrawita, E. (2019). Dampak Negatif Penggunaan Gadget (Handphone) Dalam Pengelolaan Waktu Belajar Anak Usia SMP Di Rt o1 Kelurahan Pelabuhan Baru.

Sigman, K. (2011). New Frontiers In Applied Probability Exact Simulation Of The Stationary Distribution Of The Fifo M/G/C Queue Exact Simulation Of The Stationary Distribution Of The Fifo M/G/C Queue. J. Appl. Prob. Spec, 48(August), 209-213. http://www.columbia.edu/ ks20/papers/JAP-KS-Exact.pdf

Sinta, Muhamad Ali, H. (2018). Pengaruh Gadget terhadap Perkembangan Sosial Anak di TK Aisyiyah Bustanul Athfal. Jurnal Pendidikan Dan Pembelajaran Khatulistiwa, 7(2). https://jurnal.untan.ac.id/index.php/jpdpb/article/view/23853

Soetjingsih \& Ranuh, G. (2013). Tumbuh kembang anak. edisi 2. EGC.

Sulton. (2013). Anak dan Gadget: Yang Penting Aturan Main. Nikita. Id. https://nakita.grid.id/read/o27841/anak-dan-gadget-yang-penting-aturan-main?page=all

Syaodih, E. (2004). Bimbingandi Taman Kanak-kanak. Dikti Depdiknas.

Tan Paulus, F. (2016). Pengaruh Gadget dalam Interkasi Sosial Anak Usia Dini”. Fakultas Ilmu Sosial dan Humaniora.

Trinika, Y. (2015). Pengaruh Penggunaan Gadget Terhadap Perkembangan Psikososial Anak.

Wenty, A. (2011). tentang Keterlambatan Bicara (Speech Delay) pada Anak (Studi Kasus Anak Usia 5 Tahun). http://lib.unnes.ac.id/2802/

Widiawati, L., Sugiman, H., \& E. (2014). Pengaruh Penggunaan Gadget Terhadap Daya Kembang Anak. In rosiding Seminar Nasional Multidisiplin Ilmu.

Yulia Eka Salnita, Atmazaki Atmazaki, A. A. (2019). Pemerolehan Bahasa pada Anak Usia 3 Tahun. Obsesi,3(1). https://doi.org/https://doi.org/10.31004/obsesi.v3i1.156

Yulsyofriend. (2013). Permainan Membaca dan Menulis Anak Usia Dini. Sukabina Press.

Yulsyofriend, Y., Anggraini, V., \& Yeni, I. (2019). Dampak Gudget Terhadap Perkembangan Bahasa Anak Usia Dini. Pedagogi : Jurnal Anak Usia Dini Dan Pendidikan Anak Usia Dini, 5(1), 25. https://doi.org/10.30651/pedagogi.v5i1.2889

Yunita, S. dan P. S. R. (2020). Bermain Peran: Sebuah Metode untuk Meningkatkan Kemampuan $\begin{array}{llll}\text { Bahasa } & \text { Ekspresif } & \text { Obsesi, } & \text { 5(1). }\end{array}$ https://doi.org/https://doi.org/10.31004/obsesi.v5i1.509

Zemliansky, P., Wilcox, D. (2010). Design and Implementation of Educational Games: Theoretical and Practical Perspectives. IGI Global. 